\title{
HET GEREFORMEERD KERKELIJK LEVEN IN CURAÇAO
}

\author{
DOOR \\ J. C. HOUTZAGERS \\ Geref. predikant te Voorschoten
}

Gevraagd om in dit tijdschrift iets mee te deelen over de ontwikkeling van het Gereformeerd kerkelijk leven op Curaçao, wil ik daaraan gaarne voldoen.

De Gereformeerde kerken hebben nog maar slechts enkele jaren geleden hier den arbeid ter hand genomen. Zooals den lezers bekend zal zijn, is van oudsher het grootste deel der bevolking van Curaçao Roomsch-Katholiek. Vroeger - ik spreek van eeuwen terug - was het den Creool verboden in de Protestantsche kerk te komen. Een toestand, die ons werkelijk ongelooflijk toeschijnt. Maar niettemin op grond van veler bewering als waar moet worden aangenomen. En het is de eer van de Roomsch-Katholieke kerk, dat zij haar vleugels over Curaçao en zijn bewoners heeft uitgebreid; de overwinningen van het Roomsch-Katholicisme zijn dan ook enorm groot geweest. Een groot deel van hen, die niet geacht kunnen worden tot de R.K. kerk te behooren, zijn afvalligen van die kerk.

Vandaar dat er op Curaçao voor de Gereformeerde kerken, die zelf 50 of 100 jaren bestaan, al naar gelang zij uit de Doleantie of Afscheiding zijn voortgekomen, geen zendingsveld lag. De behoefte aan een Gereformeerde kerk is pas gevoeld, toen door de nederzettingen van de Shell en de daarmee verband houdende opkomst en welvaart van Curaçao een stroom van Hollanders op Curaçao zich vestigde. Van degenen, die in dienst traden bij de C.P.I.M. of bij de politie, vonden enkele Gereformeerden elkander. En het is een jaar of acht geleden, dat eenige Gereformeerden - vier of vijf - Zondagmorgens bij elkaar kwamen ten huize van den Heer Tiesma, thans sergeant-majoor bij de militaire Politie, om een predikatie te lezen. Daar men bij de voortdurende toe- 
vloed van Hollanders naar Curaçao geen oog erop kon houden, wie krachtens doop en belijdenis tot de Gereformeerde kerken behoorden, en het vermoeden groeide, dat er toch vele Gereformeerden onder moesten schuilen, heeft men zich in verbinding gesteld met de Gereformeerde kerken van Nederland met verzoek de mogelijkheid te overwegen een predikant uit te zenden tot bearbeiding van de Gereformeerden en tot verzorging van de militairen en politie-mannen. Met dit resultaat, dat in 1934 Ds. H. W. Kroeze en zijn echtgenoote in Curaçao kwamen, uitgezonden door de Gereformeerde kerk van 's-Gravenhage-West. De eerste dienst, die gehouden werd in een door het gouvernement welwillend afgestaan zaaltje, was een belangrijke gebeurtenis voor de weinige Gereformeerden. Men wist op lange na niet hoevelen er dien eersten dienst zouden bijwonen. Men had voor vele stoelen gezorgd en bovendien nog zeventig achter de hand. Met spanning verbeidde men den eerstkomenden Zondag. En de opkomst bedroeg ....... slechts 12 personen.

Op allerlei wijze werden toen de Gereformeerden opgezocht en bearbeid, hetgeen zeer moeilijk was. Velen waren reeds jaren op Curaçao en daardoor wat vervreemd van het kerkelijk leven. Anderen hadden zelfs geheel ermee gebroken. En van degenen, die op Curaçao voor 't eerst kwamen, werden er velen van stonde aan meegesleept in de sfeer van wat men noemt, de uitgaande wereld van Curaçao. Zoo ooit, dan is aan hen in Curaçao het spreekwoord bevestigd: het zijn sterke beenen, die de weelde kunnen dragen, want weelde heerscht er in Curaçao. Niet zoo zeer - in dien zin althans - onder de gekleurde bevolking. Maar wel onder de Hollanders en de blanke Curaçaoenaars. Heel veel jongelui, uit Holland in Curaçao komend, worden uit hun oorspronkelijk milieu overgeplaatst in een anderen welstandskring. En geheel vrij van alle familie- en gezinsverband, worden vele oorspronkelijk Gereformeerde jongelui spoedig meegesleept door den geest van frivoliteit, die ook in Curaçao heerscht. Daarbij komt vooral dit. Omdat Curaçao zelf weinig of geen ontspanning biedt, zoekt men dan zijn vertier veelal in die dingen, die destructief inwerken op het geestelijk-zedelijke van den mensch. Het zedelijk leven staat dan niet hoog. Integendeel, het moet laag genoemd worden. Ik heb dan ook in den korten tijd, dat ik in Curaçao was - slechts vijf maanden - er velen zien ten ondergaan, die eenvoudig niet meer te houden waren. En dat niet alleen ongehuwden, maar ook gehuwden, wier vrouw en kinderen in het moederland waren achtergebleven. 
Toch heeft de Gereformeerde kerk aldaar door God's zegen nog velen mogen terugbrengen. En iedere Gereformeerde, die in Curaçao voet aan wal zet, belijdend lid of dooplid, wordt door de Gereformeerde kerk opgevangen. En met name voor de ongehuwden en de alleenstaande gehuwden worden de huizen wijd opengezet, om hen in het familieleven op te nemen. Langzamerhand heeft zich dan ook in de jaren 1934-1938 het groepje Gereformeerden uitgebreid. En reeds kon in 1936 een schoon kerkgebouw in gebruik genomen worden, dat plaats biedt aan 100 of meer personen. Het kerkgebouwtje staat op een van de mooiste punten van Willemstad en wordt algemeen geacht te zijn van fijne stijl en springt daardoor alleen reeds in 't oog. Want rijk aan architectuur kan Curaçao niet genoemd worden. Hoewel de Spaansch-Hollandsche geveltjes hun aparte bekoring hebben.

In den tijd, dat ik als plaatsvervanger van Ds. Kroeze tijdens diens verlof optrad gedurende de eerste jaarhelft van 1938, was het aantal Gereformeerden, behoorende tot de kerk van Curaçao 264, waarvan er echter 198 op Curaçao wonen. De anderen wonen op Aruba en in Suriname. Op Aruba zijn er 10 à 12 Gereformeerden. Vier maal per jaar worden zij bezocht door den predikant. In Suriname wordt het contact schriftelijk bewaard. De afstand is ver en de kosten zijn hoog. Op Bonaire woont - voor zoover mij bekend - geen Gereformeerde.

De Gereformeerde kerk van Curaçao is nog niet zelfstandig, maar ressorteert onder de kerk van den Haag-West en is, van kerkelijk standpunt bezien, daarvan een wijk. De kerkeraad heet dan ook wijkraad.

Deze kerk doet ook zeer veel aan evangelisatie. Door huisbezoek en door verspreiding van allerlei lectuur, tijdschriften, preeken, kalenders enz. tracht zij de boodschap des evangelies ook buiten haar eigen kring te verbreiden.

Zooals elke evangelisatie, is dit niet het minst in Curaçao een zeer moeilijke arbeid. Op geestelijk gebied is de bevolking zeer moeilijk te benaderen. De meest scheeve voorstellingen hebben zich in den geest van de naïeve menschen vastgezet .Zoo wilde een zwarte Curaçaoenaar - het zal den lezers bekend genoeg zijn, dat er blanke en zwarte Curaçaoenaars zijn - eens beweren, dat God met den zwarten mensch niet van doen wilde hebben. Hij baseerde zijn meening op het feit dat, hij „nog nooit een zwarten God op een plaatje gezien had. God is alleen voor den "witten" mensch en de duivel is voor den zwarten mensch. Want die moet toch ook menschen hebben en de duivel is zwart." En ook uit de 
praktijk van zijn leven was dit voor hem komen vast te staan. Het regende altijd - zoo zei hij - tusschen 12 en 1 uur en na 4 uur en haast nooit voor 12 en na 1. Daarmee bedoelde hij dit: onder mijn werktijd regent het nooit. Maar altijd in mijn schafttijd of vrijen tijd. Wanneer het in zijn werktijd regende, kon hij het werk staken. Dat was hem veel aangenamer. Hij bad er wel eens om, dat het toch op een anderen tijd regende. Maar „God hoort mij niet. Hij wil niet met den zwarten mensch te doen hebben. Bid u maar voor me. Hij hoort naar u wel." Een enkel staaltje van den naïeven geest van dit deel der bevolking, dat gemakkelijk met meerdere zou zijn aan te vullen. Maar genoeg. Kinderen zijn het, groote kinderen.

En daarom vraagt de Gereformeerde evangelisatie zeer veel geduld en toewijding. Het is voor haar zeer moeilijk om de beginselen van het evangelie ingang te doen vinden. Want wel zijn de eeuwige dingen juist den eenvoudigen geopenbaard, toch is dit de gang: door het hoofd naar het hart.

De Gereformeerde evangelisatie onder de kleurlingen heeft dan ook, voor zoover mij bekend is, tot dusver in het geheel geen resultaat opgeleverd, maar dat werk is nog niet intensief ter hand genomen, daar de opbouw van het eigen kerkelijk leven alle aandacht vroeg.

Tot de Gereformeerde kerk behoort geen enkele echte Curaçaoenaar. Wèl heeft eenig resultaat gehad de bearbeiding van de Surinamers door de Gereformeerde kerk. Er wonen op Curaçao ongeveer 400 Surinamers, sommigen reeds 10 jaar. Hoewel voor 't grootste deel van origine behoorend tot de Evangelische Broedergemeente in Suriname, zijn zij meerendeels van het geloof vervreemd. Daar de Hernhutters een andere liturgie hebben, heeft de predikant van de Gereformeerde kerk, Ds. H. W. Kroeze, eenige jaren geleden getracht aparte diensten voor hen in te stellen.

Eerst maakten die diensten nog al eenigen opgang. Maar heel spoedig trad het verval in. Eerst kwamen er circa veertig. Toen liep het terug tot acht. En tenslotte niet één. $\mathrm{Al}$ is het doel niet bereikt, toch is er nog wel contact uit ontstaan en bewaard gebleven tusschen de Surinamers en de Gereformeerde kerk van Curaçao. Op verzoek van de Evangelische Broedergemeente te Paramaribo verricht de Gereformeerde predikant bepaalde kerkelijke handelingen, zooals b.v. huwelijksbevestiging en doop. Zelfs wordt ook nog wel op Christelijke feestdagen een dienst naar hun liturgie gehouden. Waarvoor dan gemeenlijk nog wel belangstelling is. Dat de Evang. Broedergemeente van Suriname en de Ge- 
reformeerde predikant met elkander in contact staan, vindt zijn oorzaak daarin, dat er geen geïnstitueerde gemeente van de Hernhutters op Curaçao is. De Surinamers voelen zich nog het meest aangetrokken tot de Gereformeerde kerk. Toch zijn het nog maar enkelen, die min of meer trouw kerkelijk meeleven.

Onder het kerkelijk leven van Curaçao moet ook gerekend de verzorging van de militairen. Het is den lezers bekend, dat er in het Waterfort een bezetting is van mariniers en dat er in het Schottegat steeds een oorlogsschip ligt. Onder deze mannen zijn vanzelf ook Gereformeerden. De mariniers van het Waterfort en de matrozen en korporaals van het oorlogsschip worden iederen Donderdagavond verwacht in de pastorie, die er op gebouwd is om velen te ontvangen. Dat zijn de marine-avonden. Daar is toegang voor allen. Er wordt niet gevraagd naar richting of kleur. De marine-avond begint met een toespraak van ongeveer een half uur over allerlei onderwerpen op bijbelsch en staatkundig terrein. Daarna wordt onder het genot van een koelen dronk gesjoeld, gedamd en geschaakt. En zoo tracht men de militairen in een huiselijk milieu op te nemen en hen onder een anderen invloed te brengen.

Ook gaat de belangstelling van de Gereformeerde kerk zeer uit naar de zeevarenden. $Z$ ij, die op passagiers- en koopvaardijschepen varen, krijgen regelmatig toezending van lectuur en worden aan boord bezocht. Velen vinden uit zichzelf, zoodra zij Curaçao aandoen, den weg naar de pastorie.

Zoo is dan het Gereformeerd kerkelijk leven van Curaçao nog zeer klein, maar toch in enkele jaren in ledental overweldigend uitgebreid, vergeleken met het klein getal, waarmee het begon. En de Gereformeerde kerk, niet het minst door het opvallend aardige kerkgebouw op Mundo Nobo, heeft op Curaçao eenig aanzien naar buiten gekregen. 